УДК 811.511 .24

DOI 10.17223/18137083/59/12

\title{
С. С. Буторин
}

Институт филологии СО РАН, Новосибирск

Новосибирский государственный технический университет

\section{Типологические особенности выражения \\ компонентов ситуации местонахождения в кетском языке: структурно-семантический анализ неглагольных предикатов}

Рассмотрены основные структурные особенности и пространственная семантика компонентов моделей выражения локативной ситуации местонахождения посредством системы неглагольных предикатов. Данная система включает следующие разновидности: субстантивные, субстантивно-послеложные, прономинальные, прономинально-послеложные, адвербиальные предикаты, а также неглагольные предикаты, выраженные описательными оборотами с некоторыми пространственными именами. Показано, что в состав субстантивных, субстантивно-послеложных, прономинальных и прономинально-послеложных предикатов входят имена, оформленные эссивными падежами - локативом и адессивом. Выявлены основные типологические особенности выражения предикатов местонахождения в кетском языке.

Ключевые слова: кетский язык, пространственная ситуация местонахождения, неглагольный предикат, структурные и семантические типы неглагольных предикатов местонахождения, типологическая характеристика.

Целью статьи является рассмотрение основных средств выражения статических локативных ситуаций местонахождения (локализации) объекта относительно ориентира. К типологическим своеобразиям кетского языка в плане выражения пространственных отношений относится отсутствие экзистенциальных глаголов, которые в общей форме указывают на существование локализуемого объекта в какой-либо области пространства, например: рус. быть, находиться (см.: [Гак, 1996, с. 13]). Точнее, в кетском языке не представлены глагольные предикаты, выражающие идею экзистенции / локализации в наиболее общем виде. Однако

Буторин Сергей Сергеевич - кандидат филологических наук, старший научный сотрудник Сектора тунгусо-маньчжуроведения Института филологии СО РАН (ул. Николаева, 8, Новосибирск, 630090, Россия); доцент кафедры иностранных языков технических факультетов Новосибирского государственного технического университета (просп. К. Маркса, 20, Новосибирск, 630073, Россия; butorin_ss@mail.ru)

ISSN 1813-7083. Сибирский филологический журнал. 2017. № 2

(C) С. С. Буторин, 2017 
статические локативные ситуации могут выражаться глаголами положения в пространстве (позиционными глаголами).

Главным образом семантика местонахождения передается синтаксическими локативными конструкциями с неглагольными предикатами. Локативные неглагольные предикаты оформляются постпозитивными предикативными показателями, координирующими предикат с подлежащим по категориям лица, класса и числа. При этом такие показатели выполняют функцию связки - глагольная связка в кетском отсутствует. Основное отличие кетских показателей от стандартных аффиксов заключается в том, что они, как клитики, постпозитивно присоединяются к словоформам независимо от их категориальной принадлежности и морфемного состава (допускают присоединение к прилагательным, наречиям, существительным и к финальному компоненту послеложной конструкции).

Данная работа является продолжением исследования неглагольных локативных предикатов в кетском языке, некоторые результаты которого изложены в статье автора [Буторин, 2015].

Под неглагольным предикатом, вслед за К. Хенгевельдом [Hengeveld, 1992, p. 26], мы понимаем предикат, в котором главным компонентом является слово, не принадлежащее классу полнозначных глаголов, вне зависимости от того, содержится ли в составе сказуемого глагол-связка.

В кетском языке существуют три стратегии кодирования неглагольных предикатов: нулевая (оформление предикативными показателями отсутствует), лично-предикативная и нелично-предикативная стратегии. Для кодирования неглагольных локативных предикатов используются преимущественно личнопредикативная и редко нелично-предикативная. Лично-предикативная стратегия предполагает оформление локативного предиката лично-предикативными показателями ряда $\partial u / \partial y$, а нелично-предикативная - оформление предиката неличнопредикативными показателями $c^{\prime}$ (ед. ч.) / $c^{\prime}=u н$ (мн. ч.).

В результате проведенного исследования построена классификация структурных типов неглагольных локативных предикатов на основе способа выражения основного семантического компонента - ориентира и стратегии предикативного кодирования:

I. Лично-предикативные неглагольные конструкции, включающие:

1) субстантивный предикат в одном из эссивных падежей (локативе или адессиве);

2) субстантивно-послеложный предикат;

3) прономинальный предикат;

4) прономинально-послеложный предикат;

5) адвербиальный предикат;

6) неглагольные предикаты, выраженные описательными оборотами с некоторыми пространственными именами, в частности қ̧ол'еn 'сторона, половина', баң 'место', 'земля'.

II. Нелично-предикативные неглагольные конструкции, представленные субстантивно-послеложным предикатом.

В данной работе рассматриваются структурные характеристики и пространственная семантика выделенных разновидностей неглагольных локативных предикатов. Общей семантической характеристикой этих предикатов является то, что они имеют эссивное пространственное значение, т. е. указывают на статическую локализацию объекта относительно ориентира.

Перед тем, как мы перейдем к рассмотрению кетского языкового материала, необходимо отметить следующее. Примеры приводятся в авторской записи, при этом в ряде случаев пришлось применить определенное упрощение и унификацию используемых фонетических символов. Таблица соответствия фонетических знаков некоторых систем приведена в [Кетский сборник, 1969, с. 284-285]. Сле- 
дует обратить внимание на то, что в кетологической литературе отсутствует унифицированная система транскрипции; ряд исследователей использует систему на основе латиницы, другие же - на основе кириллицы, причем как у первых, так и у последних отсутствует единая унифицированная транскрипционная система.

\section{1. Лично-предикативные конструкции}

1.1. Субстантивный предикат. Субстантивный локативный предикат имеет в качестве своего структурного центра имя существительное, называющее ориентир, относительно которого локализуется объект. При этом имя существительное оформляется показателем одного из эссивных падежей: локативного (местновременного) или адессива (местно-личного). Показатель локативного падежа представлен алломорфами $к a \sim z a \sim \gamma a \sim \gamma c e \sim \kappa c$, которые не отражают категории класса и числа имени существительного. Показатели адессива дифференцируют класс и число оформляемого ими существительного: в ед. ч. мужской класс $\partial=a=\mu m m a$, женский $-\partial=u=\mu ̧ m a$, неодушевленный (вещный) $-\partial u=\mu ң m a$ (падежные показатели женского и неодушевленного классов совпадают). Во мн. ч. противопоставлены одушевленный класс, объединяющий мужской и женский классы и репрезентируемый показателем $H=a=\mu ̧ m a$, и неодушевленный, выраженный показателем $\partial=u=\mu m а$ и совпадающий с соответствующим показателем класса вещей (а также женского класса) в ед. ч. Таким образом, в вещном классе показатели адессива ед. ч. и мн. ч. не противопоставлены. Падежные показатели в составе субстативного предиката приведены в табл. 1.

Таблища 1

Эссивные падежные показатели Essive case markers

\begin{tabular}{|c|c|c|c|c|}
\hline \multirow{2}{*}{ Падеж } & \multicolumn{2}{|c|}{ Единственное число } & \multicolumn{2}{|c|}{ Множественное число } \\
\hline & $\begin{array}{c}\text { мужской } \\
\text { класс }\end{array}$ & $\begin{array}{c}\text { женский } \\
\text { и вещный класс }\end{array}$ & одушевленное & неодушевленное \\
\hline Локатив & \multicolumn{2}{|c|}{$\kappa a \sim z a \sim \gamma a \sim \gamma c e \sim \kappa c e$} & \multicolumn{2}{|c|}{$\kappa a \sim z a \sim \gamma a \sim \gamma c e \sim \kappa a$} \\
\hline Адессив & $\partial=a=$ н̧ma & $\partial=u=\langle ̧ m a$ & $H=a=\not ̧ m a$ & $\partial=u=\langle ̧ m a$ \\
\hline
\end{tabular}

Таблица 2

Лично-предикативные показатели (суффиксы) ряда $\partial и / \partial y$ Personal predicative markers (suffixes) of the $\partial u / \partial y$ paradigmatic series

\begin{tabular}{|c|c|c|}
\hline Лицо & Единственное число & Множественное число \\
\hline $1-\mathrm{e}$ & $\partial u \sim p u$ & 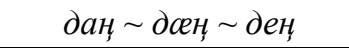 \\
\hline $2-\mathrm{e}$ & $\kappa y \sim 2 y \sim \gamma y$ & 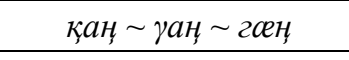 \\
\hline 3-е мужской класс & $\partial y \sim p y \sim \partial o \sim p o$ & 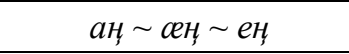 \\
\hline 3-е женский класс & $\partial a \sim p a$ & 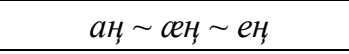 \\
\hline 3-е вещный класс & $a M \sim a e M \sim e M$ & $a M \sim a e M \sim e M$ \\
\hline
\end{tabular}

Есть основания различать две разновидности субстантивного локативного сказуемого: 1) сказуемое, в составе которого локативная падежная форма существительного оформляется лично-предикативными показателями ряда $\partial u / \partial y$ (наиболее 
распространенный случай; см. табл. 2, а также работу [Буторин, 2015, с. 145-148]), и 2) сказуемое, в составе которого локативная падежная форма существительного не оформляется лично-предикативными показателями ряда $\partial u / \partial y$ (более редкий случай).

Ниже представлены примеры использования неглагольных субстантивных предикатов, содержащих показатели локативного (1) и адессивного (2) падежей и оформленных лично-предикативными показателями ряда $\partial u / \partial y$.

(1)

$$
\begin{array}{ll}
\text { Богдом } & \text { амбал }=г е=j=е м . \\
\text { ружье.ABS.N } & \text { амбар=LOC=INTF=PRED.3.N }
\end{array}
$$

'Ружье в амбаре.' (Дульзон, 1972а, с. 111)

(2)

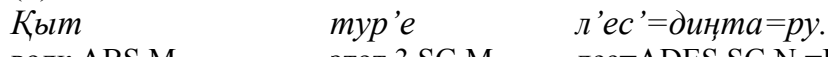

$$
\begin{aligned}
& \text { волк.ABS.M этот.3.SG.M. лес=ADES.SG.N =PRED.3.SG.M }
\end{aligned}
$$

Отмечается параллельное использование неглагольных локативных предикатов, которые в своем составе могут содержать существительное либо в локативном падеже, либо в адессивном [Werner, 1997, S. 114-115]. Данный факт можно отнести к явлениям конкуренции падежного оформления имен, вызванной, возможно, былыми диалектными различиями в морфологической маркировке имен, которые, однако, трудно проследить на современном уровне состояния диалектного членения кетского языка, обусловленного миграцией носителей кетского языка в советский и постсоветский периоды истории России. Выявить семантические различия вариативной падежной маркировки на данном этапе исследования не представляется возможным.

(3)

$$
\begin{array}{ll}
\text { Богдом } & \text { амбал }{ }^{\prime}=г е=j=е м . \\
\text { ружье.ABS.N } & \text { амбар }=\mathrm{LOC}=\mathrm{INTF}=\mathrm{PRED} .3 . \mathrm{N}
\end{array}
$$

'Ружье в амбаре.' (Дульзон, 1972а, с. 111)

(4)

$$
\begin{array}{lc}
\text { Богдом } & \text { амбал'=дингте }=\text { м. } \\
\text { ружье.ABS.N } & \text { амбар=ADES=PRED.3.N } \\
\text { 'Ружье в амбаре.' (Там же) }
\end{array}
$$

Наблюдается параллельное использование оформленных и не оформленных предикативными суффиксами падежных форм:

(5)

$\begin{array}{ll}\text { Бен } & \partial^{\prime} e=\text { диңта }=p^{\prime} a, \\ \text { утка.ABS.F } & \text { озеро=ADES=PRED.3.SG.F } \\ x y ? m & \text { улбангта= } m a . \\ \text { хвост.ABS.N } & \text { берег=LOC }\end{array}$

хвост.ABS.N берег $=$ LOC

'Утка в озере, а хвост на берегу.' (Ср. русскую загадку: «Утка сама в море, хвост ее на заборе» (Ковш).) (Дульзон, 1972а, с. 135)

В составе субстантивного локативного предиката может использоваться не только предметный (примеры (3)-(5)), но и личностный (6) ориентир, т. е. ориентир, референтом которого является лицо [Серээдар и др., 1996, с. 20, 27-30]. 
(6)

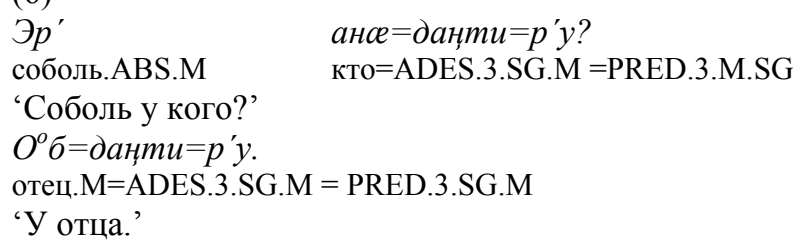

Личностные ориентиры выражаются как недейктически (номинациями свойства и родства, социального статуса и т. д.), так и дейктически (чаще всего местоимениями). В первом случае используются конструкции с субстантивными, субстантивно-послеложными предикатами и предикатами, выраженными описательными оборотами с пространственными именами, а в последнем - конструкции с прономинальными, прономинально-послеложными предикатами и предикатами, выраженными описательными оборотами.

Подробности и примеры приведены в разделах 1.2-1.4, 1.6.

1.2. Субстантивно-послеложный предикат. В качестве стержневого компонента субстантивно-послеложного предиката используется притяжательная конструкция, состоящая из существительного и послелога.

Имеются две стратегии предикативного кодирования субстантивно-послеложного неглагольного предиката: лично-предикативная и нелично-предикативная (см. раздел 2). В данном разделе рассматриваются лично-предикативные конструкции.

Предикат в субстантивно-послеложных конструкциях указывает не только на ориентир, но и на топологическую зону ориентира (верхняя поверхность, нижняя поверхность, фронтальная сторона, пространство перед ориентиром, пространство сзади ориентира и т. д.). Аналогичные конструкции отмечены и в тюркских языках Южной Сибири (см.: [Невская, 2005, с. 141-143]).

Структура неглагольного субстантивно-послеложного предиката следующая: первый компонент, выраженный субстантивом и оформленный показателем родительного падежа (генитива) (см. табл. 3), который отражает число, а в единственном числе - класс (мужской, женский и вещный) первого компонента, пространственный послелог, содержащий показатель локативного падежа, и личнопредикативный показатель.

Таблица 3

Показатели генитива

Genitive markers

\begin{tabular}{c|c|c|c}
\hline \multicolumn{2}{c|}{ Единственное число } & \multicolumn{2}{c}{ Множественное число } \\
\hline \multirow{2}{*}{ мужской класс } & $\begin{array}{c}\text { женский } \\
\text { и вещный класс }\end{array}$ & одушевленное & неодушевленное \\
\hline$\partial a$ & $\partial(u)$ & $н a$ & $\partial(u)$ \\
\hline
\end{tabular}

Пространственные послелоги частично сохраняют именную словоизменительную парадигму, что характерно для служебных имен и в других языках, в частности в тюркских [Невская 2005, с. 140-143]. Послелоги с эссивным значением со-

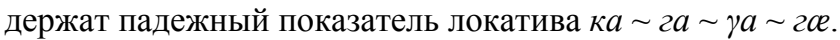

Субстантивный компонент может иметь препозитивное определение (7). 
(7)

$\begin{array}{ll}\text { Тьлн' } & \text { вин } \\ \text { озеро.ABS.N } & \text { два } \\ \text { аж=на } & \text { винбал' }=\gamma a=j=а л\end{array}$

деревья=GEN.PL.AN между.PPS $=\mathrm{LOC}=\mathrm{INTF}=$ PRED.3.N

'Котел между двух деревьев.' (Романенкова, 2009)

Семантическая структура послеложной конструкции имеет композиционный характер. Имя в составе послеложной конструкции называет ориентир, относительно которого локализуется объект в конкретной локативной ситуации. Послелог указывает на топологическую зону окрестности ориентира. Ориентир мыслится как объект, организующий вокруг себя некоторое пространство, которое делится на целый ряд топологических зон (внешняя, внутренняя, передняя, верхняя и т. п.) [Мельчук, 1998, с. 52-54; Плунгян, 2000, с. 175-178; Плунгян, 2002, c. 66-68]. Показатель локативного падежа передает эссивное значение.

Композиционный характер пространственной семантики локативных выражений вообще и послеложной конструкции в частности отмечается и в других языках, например в уральских и тюркских [Kracht, 2002, p. 159-160; 2005; Невская, 2005, с. 139-143].

Не все основы послелогов, в которых формально выделяются падежные показатели, поддаются этимологизации и могут быть соотнесены с основами, бытующими на данном этапе функционирования языка. Поэтому основы послелогов глоссируются как PPS - основа послелога и при глоссировании дается русский семантический эквивалент всего послелога.

Приведем примеры наиболее характерных синтаксических структур с неглагольным субстантивно-послеложным предикатом, называющим ситуации местонахождения с указанием типа топологической зоны ориентира, относительно которой локализуется объект (8)-(20).

ИН-эссивное значение (локализация в пространстве внутри ориентира) выражается послелогом хыјza 'внутри' (< xыj 'нутро, внутренность' + LOC), причем этот послелог может указывать как на локализацию внутри полого ориентира (8), так и на локализацию в сплошной среде (9).

(8) Локализация внутри полого объекта.

Д'blл'

мальчик.ABS.M

$y j=m \quad x b l j=2 a=\partial y$

люлька.N=GEN.3.N внутри.PPS=LOC=PRED.3.SG.M

'Ребенок (мальчик) в люльке.' (Романенкова, 2009)

(9) Локализация в сплошной среде.

Дон ${ }^{\prime} \quad \boldsymbol{л}^{\prime}=m$

нож.ABS.N вода $=$ GEN.3.N

$x b l j=\gamma a=j=e$ M

внутри.PPS $=\mathrm{LOC}=\mathrm{INTF}=\mathrm{PRED} .3 . \mathrm{N}$

'Нож в воде.' (Там же)

АПУД-эссивное значение (локализация в любой области пространства рядом с ориентиром/вблизи ориентира) передается посредством послелогов ыл'га 'около, возле, рядом; снаружи' (< blл' $\boldsymbol{l}$ ' 'наружное пространство' + LOC) (10) и мл'гитка 'возле помещения, снаружи' (< blл' $л^{\prime}$ 'наружное пространство' + кат гит 'край' + LOC) (11). 
(10)

Унцокс ${ }^{\prime} \quad \pi^{\prime} a м=\partial \quad$ вил $=2 a=j=э м$

стул. ABS.N стол=GEN.3.N возле.PPS=LOC=INTF=PRED.3.N

'Стул возле стола.' (Романенкова, 2009)

(11)

Ac'luн $\quad k o ? c(<k y ? c)=\partial$

лодка.-ABS.N чум $=$ GEN.3.N

u' 2 $2 \mathrm{~m}=\kappa a=j=a \mathrm{M}$

возле.PPS $=$ LOC $=$ INTF=PRED.3.N.

'Лодка возле чума.' [Дульзон, 1968, с. 575]

АД-эссивное значение (локализация на поверхности объекта) выражается послелогом ^:тка < лүатка 'на':

(12)

$\begin{array}{ll}\text { Сақ } & \pi^{\prime} a \mu^{\prime}=\partial \\ \text { белка.ABS.F } & \text { стол=GEN.3.N } \\ \iota m=\kappa a=j=\partial a & \end{array}$

на.PPS $=$ LOC $=$ INTF $=$ PRED.SG.3.F

'Белка на столе.' (Романенкова, 2009)

СУПЕР-эссивное значение (локализация в пространстве над ориентиром) может передаваться тем же послелогом и.mка 'над’ (13). Данное обстоятельство позволяет предположить, что в кетском языке четкое противопоставление контактной и неконтактной локализации объекта относительно верхней части ориентира (т. е. дифференциация АД-эссивного и СУПЕР-эссивного значений) отсутствует.

(13)

\begin{tabular}{|c|c|}
\hline $\begin{array}{l}\text { Tын' ' } \\
\text { котел.ABS.N }\end{array}$ & $\begin{array}{l}\text { богдот }=\partial \\
\text { очаг }=\text { GEN.3.N }\end{array}$ \\
\hline \multicolumn{2}{|l|}{$\wedge m=\kappa a=j=e м$} \\
\hline $\begin{array}{l}\text { над.PPS=LOC } \\
\text { 'Котел над о }\end{array}$ & ED.3.N \\
\hline
\end{tabular}

СУБ-эссивное значение (локализация под ориентиром, под нижней поверхно-

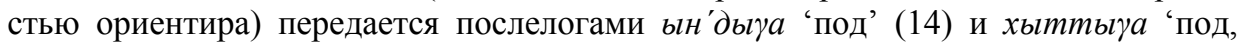
внизу' (15).

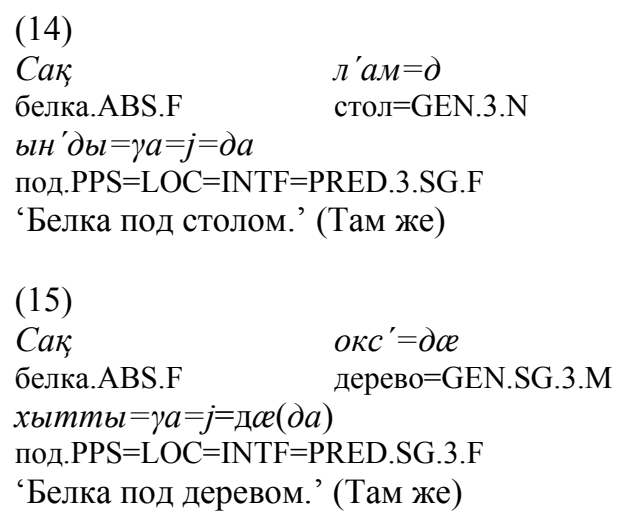


ИНТЕР-эссивное значение (локализация в пространстве между элементами множества или совокупности, служащими ориентиром) маркируется послелогом ьнббал' 'между':

(16)

$\begin{array}{lll}\text { Тылн' } & \text { вын } & \text { ақ =на } \\ \text { котел.ABS.N } & \text { два } & \text { дерево.=GEN.PL.AN }\end{array}$

bاнбал ${ }^{\prime}=\gamma b l=j=a \mu$

между.PPS $=$ LOC $=\mathrm{INTF}=$ PRED.3.N.

'Котел между двух деревьев.' (Романенкова, 2009)

АНТЕ-эссивное значение (локализация в пространстве перед ориентиром) передается послелогом купка 'перед':

(17)

$\begin{array}{ll}\text { Дон' } & \kappa y c '=m \\ \text { нож.ABS.N } & \text { чум GEN.3.N. } \\ \kappa y n=\kappa a=j=c e м & \\ \text { перед.PPS=LOC=INTF=PRED.3.N } & \\ \text { 'Нож перед чумом.' (Там же) }\end{array}$

МЕДИ-эссивное значение передается послелогом таткыүа 'посередине':

(18)

Богдот $\quad \kappa y c^{\prime}=m$

очаг.ABS N чум $=$ GEN.3.N

таткыl $=\gamma a=j=a \mathrm{M}$

посередине.PPS=INTF=PRED.3.N

'Очаг посередине чума.' (Там же)

В качестве средства выражения ПОСТ-эссивного значения зафиксировано использование неглагольных предикатов, выраженных описательными оборотами (см. раздел 1.6).

(19)

$\begin{array}{llll}\text { Дон' } & y \kappa & \text { оңта } & \text { қол' } е л=\kappa a=j=\propto м м \\ \text { нож.ABS.N } & \text { твой } & \text { задний } & \text { сторона=LOC=INTF=PRED.3.N }\end{array}$

'Нож позади тебя (с твоей задней стороны).' (Там же)

Субстантивно-послеложные предикаты используются как с предметными (8)(18), так и личностными ориентирами (20).

(20)

\begin{tabular}{|c|c|c|}
\hline $\begin{array}{l}\text { Дон' } \\
\text { нож.ABS.N }\end{array}$ & $\begin{array}{l}\text { об=д } a \\
\text { отец GEN.SG.3.M }\end{array}$ & $\begin{array}{l}\kappa y n=\kappa a=j=\alpha е м \\
\text { перед.PPS=LOC=PRED.3.N }\end{array}$ \\
\hline
\end{tabular}

'Нож перед чумом.' (Там же)

1.3. Прономинальный предикат. Прономинальные предикаты в отличие от субстантивных и субстантивно-послеложных и отчасти предикатов с описательными пространственными оборотами, характеризующих местонахождение локализуемого объекта чаще всего относительно предметного ориентира, включают в свой состав прономинально выраженный семантический компонент, локализующий объект относительно личностного ориентира [Серээдар и др., 1996, с. 20, 27-30]. При этом прономинальный компонент в кетском языке вследствие 
своего лексико-грамматического значения всегда содержит дейктическое указание на ориентир.

Особенностью кетского языка является то, что личное местоимение 3-го лица всегда указывает на одушевленное лицо. Личное местоимение, которое могло бы анафорически замещать имя существительное неодушевленного (вещного) клас$\mathrm{ca}$, референтом которого является неодушевленный объект, в кетском языке отсутствует. В таких ситуациях чаще всего используются соответствующие полные именные группы.

Ранее уже отмечалось, что личностные ориентиры в коммуникативной позиции ремы могут использоваться в качестве компонентов сказуемого только в локативных предложениях, например, в русском языке предложения типа Деньги y меня имеют локативное, а не посессивное значение. При этом локализаторы данного типа могут занимать позицию сказуемого (предиката) лишь в локативных предложениях [Арутюнова, 1976, с. 239-240].

Аналогом русских локализаторов типа у меня являются кетские предикативно оформленные прономинальные личностные локализаторы, иными словами, личные местоимения в адессивном падеже, выступающие в синтаксической функции неглагольного сказуемого (21).

(21)

Тел' да каиҮина̊ - кало:о: кало:о: мана̊ даҮ а kай да бул'баул'тет,

буд ин $\quad a=$ вынгт $=е м$

еe коготь.ABSN. я=ADES.SG.1=PRED.3.N.

'Акула сказала: «Внучек, внучек, орлица хотела меня схватить ногой, ее коготь у меня».' (Дульзон, 1969, с. 183)

1.4. Прономинально-послеложный предикат. Прономинально-послеложные предикаты вместо субстантивного компонента, выраженного именем существительным, обозначающим ориентир, имеют в своем составе притяжательное местоимение. Таким образом, прономинально-послеложная конструкция состоит из притяжательного местоимения и послелога и оформляется лично-предикативными показателями, кореферентными подлежащему, называющему локализуемый объект.

Следует заметить, что притяжательные местоимения, как отмечается большинством исследователей кетского языка, в формальном плане восходят к формам родительного падежа (генитива) личных местоимений [Werner, 1997, S. 133 136; Vajda, 2004, p. 29-30].

Прономинально-послеложная конструкция используется в том случае, если ориентиром является лицо, человек, при этом ориентир задается дейктически. Если личностный ориентир задается недейктически и выражен именем существительным (например, именами родства, наименованиями профессий, именем собственным и т. д.), используется субстантивно-послеложная конструкция.

Прономинально-послеложные неглагольные предикаты передают, например, следующую локативную семантику (22)-(25):

АПУД-эссивное значение передается послелогом ыл'га/ыл' $\gamma a$ 'рядом, возле, около':

(22)

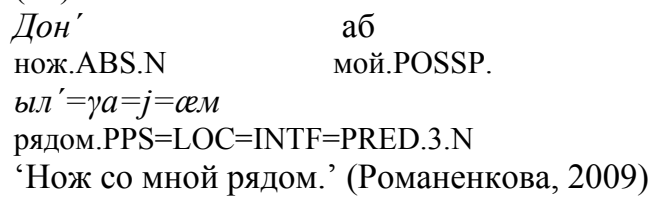


(23)

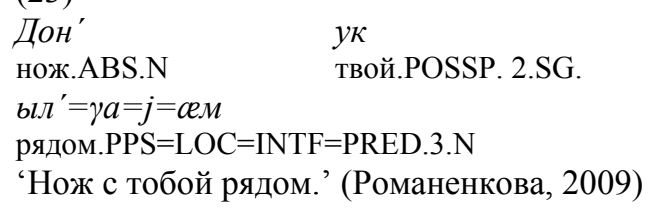

АНТЕ-эссивное значение - послелог купка 'перед':

(24)

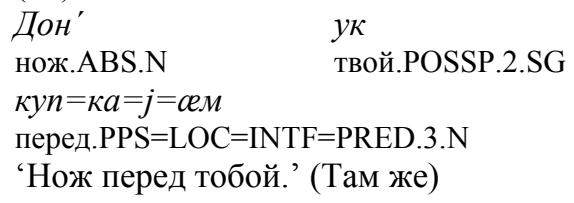

СУБ-эссивное значение - послелог ындиүа 'под’:

(25)

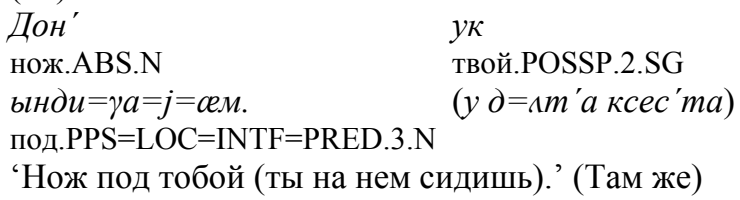

1.5. Адвербиальный предикат. В качестве ядра в адвербиальном предикате используются некоторые семантические разряды локативных наречий (см. (26)(32)), а именно:

1. Дейктические локативные наречия:

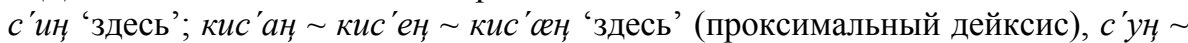

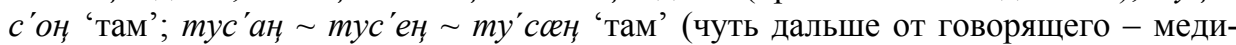

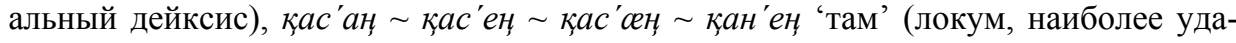
ленный от говорящего и слушающего - экстремальный дейксис) (см.: [Крейнович, 1968б, с. 461-462; Невская, 2005, с. 28, 83-84]) и некоторые другие. Например:

(26)

\begin{tabular}{|c|c|c|}
\hline Иm(H)a & $\begin{array}{l}\kappa y c^{\prime} \\
\text { чyм.ABS.N } \\
\kappa y c^{\prime}\end{array}$ & 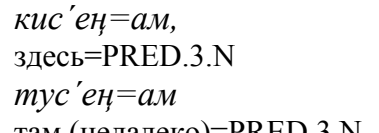 \\
\hline
\end{tabular}

там=PRED.3.N

канен =ам

там (подальше)=PRED.3.N

'Наш чум здесь, их чум там / там далеко.' (Романенкова, 2009)

(27)

Ба:m комал $\quad c^{\prime} о \nu^{\prime}=\partial y$

старик.ABS.M подальше там=PRED.3.M

'Старик подальше вон там.' [Дульзон, 1968, с. 575] 
2. Вопросительные локативные наречия, например бис' $а ң$ :

(28)

\begin{tabular}{|c|c|c|}
\hline $\begin{array}{l}\text { Бисен }=\text { ам } \\
\text { где=PRED.3.N }\end{array}$ & $\begin{array}{l}\text { қот }=\partial b \\
\text { щука }=\text { GEN. SG.3.M }\end{array}$ & $\begin{array}{l}\xi^{o} \breve{u} \gamma b . \\
\text { голова.ABS.N }\end{array}$ \\
\hline
\end{tabular}

3. Составные локативные наречия неопределенности, например там бис'аң 'там где-то':

(29)

\begin{tabular}{|c|c|c|}
\hline $\begin{array}{l}\text { До? } H^{\prime} \\
\text { нож.ABS.N }\end{array}$ & $\begin{array}{l}c^{\prime} \mathrm{OH} \\
\text { там }\end{array}$ & $\begin{array}{c}\text { там бис' } а ң=а м \\
\text { где-то=PRED.3.N }\end{array}$ \\
\hline
\end{tabular}

'Нож там где-то.' (Романенкова 2009)

4. Некоторые наречия геоцентрической ориентации, например, хытл' 'внизу':

(30)

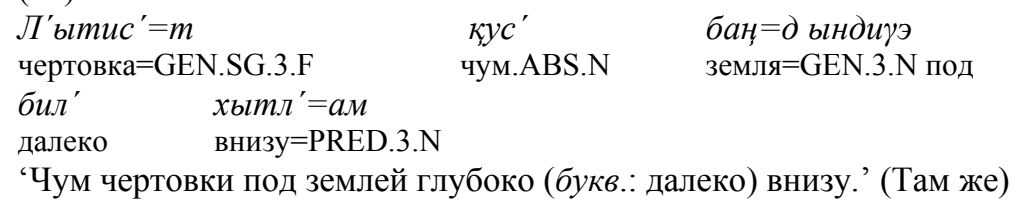

5. Наречия, указывающие на местонахождения локализуемого объекта относительно внутреннего или внешнего пространства: наречия қ̧a 'внутри (чума или иного помещения), дома' и мл' $a \sim л^{\prime} \gamma a$ 'снаружи, на улице':

(31)

$\begin{array}{llll}\text { Би:с } & a & \text { бек } & k a:=p u . \\ \text { Вечером } & \text { я } & \text { всегда } & \text { дома=PRED.1.SG } \\ \text { 'Вечером я всегда дома.' (Дульзон, } & \text { 19726, с. 68) }\end{array}$

(32)

Бам $\quad \pi^{\prime} a=p a$

старуха.ABS.F снаружи=PRED.3.SG.F

'Старуха на улице.' (Романенкова, 2009)

1.6. Неглагольные предикаты, выраженные описательными оборотами с некоторыми пространственными именами. В качестве неглагольного предиката могут использоваться атрибутивно-субстантивные словосочетания, ядром которых является существительное құол'еn 'сторона, половина'.

Существительное қ̧ол'en в неглагольном сказуемом рассматриваемого типа используется в локативном падеже и оформляется лично-предикативными показателями.

В частности, отмечено использование словосочетаний данного типа с прилагательными боүот 'правый', тулл'а 'левый', қота и оңта 'задний' в синтаксических конструкциях, описывающих статические локативные ситуации с ориентацией локализации объекта относительно антропоцентрических ориентиров 'правая/левая сторона', 'передняя (фасадная) / задняя сторона', которые передают понятия 'справа'/“слева', 'впереди'/“позади' (см., в частности [Плунгян, 2002, с. 79]) (примеры (33)-(36)). 
(33)

$$
\begin{array}{llll}
\text { Дон' } & y \kappa & \text { болот } & \text { қол'еn=кa=j=eм } \\
\text { нож.ABS.N } & \text { твой } & \text { правый } & \text { сторона=LOC=INTF=PRED.3.N }
\end{array}
$$

'Нож справа от тебя (букв.: с твоей правой стороны).' (Романенкова, 2009)

(34)

$\begin{array}{lllr}\text { Дон' } & y \kappa & \text { тулл'a } & \text { қол'ел=ка=j=eм } \\ \text { нож.ABS.N } & \text { твой } & \text { левый } & \text { сторона=LOC=INTF=PRED.3.N } \\ \text { 'Нож слева от тебя (букв.: с твоей левой стороны).' (Там же) }\end{array}$

(35)

$\begin{array}{llll}\text { Дон } & \\ \text { нож.ABS.N } & y \kappa & \text { оңта } & \text { қол'е }^{\prime}=\kappa a=j=\alpha е м \\ \text { твой } & \text { задний } & \text { сторона=LOC=INTF=PRED.3.N }\end{array}$

'Нож позади тебя (букв.: с твоей задней стороны).' (Там же)

(36)

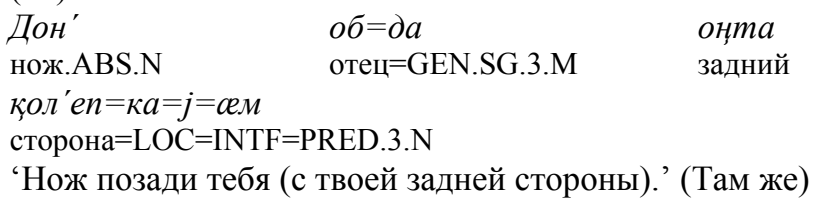

К этой разновидности неглагольных предикатов относятся также предикаты, включающие атрибутивные словосочетания, которые образованы на базе существительного баң ‘место’, ‘земля’, оформленного показателем локативного падежа:

\begin{tabular}{|c|c|c|}
\hline $\begin{array}{l}\bar{b}^{\circ} \text { mна ол } \\
\text { наш отец.ABS.M } \\
\text { банг }=2 е(\breve{u})=\partial y \\
\text { земля }=\text { LOC }=\text { PRED }\end{array}$ & $\begin{array}{l}\text { манӓ } \\
\text { говорить.3.SG.F } \\
\text { SG.M }\end{array}$ & $\begin{array}{l}\text { ташангий } \\
\text { малая ходьба }\end{array}$ \\
\hline
\end{tabular}
бой называют хождение на охоту. - С. Б.].' (Дульзон, 1972б, с. 10)

В качестве ориентиров при предикатах данного типа могут быть использованы дейктически заданные (примеры (33)-(35)) и недейктически заданные личностные ориентиры (36), а также неличностные ориентиры (37).

\section{2. Нелично-предикативные конструкции}

Стратегия оформления неглагольных субстантивно-послеложных предикатов неличным предикативным суффиксом $=c^{\prime}$ была отмечена Г. К. Вернером. Насколько можно понять, конструкцию существительное + послелог автор рассматривает как единый комплекс и относит к сложным атрибутивным сочетаниям (существительное + послелог + существительное), используемым в предикативной функции [Вернер, 2000, с. 42-43, 45-46].

Нейтральный в отношении категорий лица и числа предикативный суффикс примыкает к крайнему правому компоненту предиката, но относится ко всему предшествующему сложному образованию (словосочетанию), входящему в предикат, подчеркивая его монолитность как композита [Там же, с. 45].

Заметим, что Г.К. Вернер не проводит морфемного членения послелогов на основу и падежный показатель локатива, поэтому глоссируем послелоги как PPS + LOC. Глоссирование примеров, приводимых ниже в записи Г. К. Вернера 
(38), (39), (42), (43), а также русское глоссирование примеров Э. Вайды (40), (41) принадлежит автору настоящей статьи.

(38)

Tur'e $\quad n a^{2} n^{\prime}$
этот
aj-t-hyjga-s'
мешок- GEN.3.N-внутри.PPS+LOC-PRED
'Этот хлеб в старом мешке.' [Bepнер, 2000, c. 43]

Для сравнения приводится сочетание с препозитивным атрибутивным комплексом, не оформленным предикативным показателем:

Aj-t-hyjga

мешок- GEN.3.N-внутри.PPS+LOC

$n a^{2} n^{\prime}$

'В мешке (находящийся) хлеб.' [Там же]

Э. Вайда также считает, что в подобных конструкциях используются сложные предикаты, представленные сложными модификаторами (modifiers). При этом в данных конструкциях сложный предикат может быть оформлен либо нелично-предикативным суффиксом $c^{\prime} / c^{\prime}=u н$ (Э. Вайда считает его номинализатором), либо предикативными согласовательными аффиксами ряда $\partial u / \partial y$ [Vajda, 2004, c. 39]. Причины вариативности автор не указывает.

(40)

Ut $\quad t \dot{t} s-t-h \grave{t} t a-\gamma a-s$

мышь камень- GEN.N-низ-LOC-PRED

'Мышь (находится) под камнем.' [Vajda, 2004, p. 39]

(41)

Ut $\quad t \dot{t} s-t-h \ddot{t} t a-\gamma a-d a$

мышь камень- GEN.N-низ-LOC-PRED.F

'Мышь (находится) под камнем.' [Ibid.]

В неглагольных локативных конструкциях нелично-предикативный суффикс $c^{\prime} / c^{\prime} u=H$ используется крайне ограниченно: он может оформлять лишь предикат, представленный субстантивно-послеложной конструкцией.

Нелично-предикативные показатели, в отличие от лично-предикативных, не согласуются с подлежащим по лицу и классу. Согласование осуществляется лишь по числу: в ед. ч. $c^{\prime}$; во мн. ч. к суффиксу $c^{\prime}$ добавляется показатель мн. ч. $u н$. В материалах, приводимых Г. К. Вернером и Э. Вайдой отсутствуют примеры с подлежащими, выраженными именами множественного числа. В качестве иллюстрации согласования неличных предикатов данного типа с подлежащим по множественному числу приведем задокументированные высказывания с неглагольным предикатом иного семантического типа - квалифицирующего:

$(42)$

$\begin{array}{ll}\text { Dllas } & q \ddot{a}-k \wedge j g a-s^{\prime} \\ \text { олененок } & \text { большой-голова-PRED }\end{array}$

'Олененок большеголовый.' [Вернер, 2000, с. 42] 
(43)

$\begin{array}{lc}\text { Dllas- } n & \text { qe- } \eta \text {-kajge- } n \text { '-s'i- } n \\ \text { олененок-PL } & \text { большой-PL-голова-PL-PRED-PL } \\ \text { 'Оленята большеголовые.' [Там же] }\end{array}$

\section{3. Типологические особенности грамматического оформления неглагольных предикатов местонахождения}

1. Сказуемое не согласуется по числу с подлежащим, если подлежащее выражено именем существительным класса вещей: как в единственном, так и во множественном числе используется аффикс $=a м /=\propto ⿻ м$. Ниже приводятся два примера с существительным класса вещей: ед. ч. богдом 'ружье' (44а) и мн. ч. (ын) богдомн '(два) ружья' (44б).

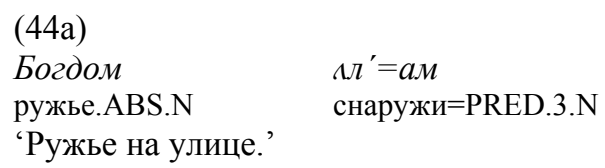

(446)

\begin{tabular}{lll} 
Ын & богдом $=H$ & \multicolumn{1}{c}{ бл'=ам } \\
два & ружье=ABS.N.PL & снаружи=PRED.3.N \\
'Два ружья на улицее.' (Романенкова, & $2009)$
\end{tabular}

Данное правило справедливо и для других разновидностей неглагольных предикатов, а не только для локативных.

2. Прошедшее время в конструкциях с неглагольным локативным сказуемым может передаваться посредством введения вспомогательного компонента, пред-

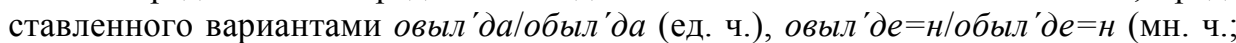
$H$ - показатель множественного числа), вероятно восходящего к глаголу «становиться» $a={ }_{6}=p^{\prime} a$ 'это=станет, будет' / $o={ }_{6}=u л ' d a$ 'это-стало, было'. Согласование (координация) по множественному числу с подлежащим имеет место лишь в том случае, если в качестве подлежащего используется имя одушевленного класса (мужского или женского) - во множественном числе используется форма овыл' $\partial е=$ н.

Как отмечает Г. К. Вернер, овыл'да (ед. ч.), овыл'дан (мн. ч.) часто сопоставляется с русским был и считается заимствованием из русского языка, что является небесспорным. В то же время кетское слово был, которое оформляется личнопредикативными суффиксами, несомненно является заимствованием из русского: был'= ди 'был-я' [Werner, 1995, S. 187].

Кстати, заметим, что по наблюдениям М. Н. Валл и И. А. Канакина, овыл'да / овыл'ден являются не глагольными формами, ввиду полного отсутствия у них каких-либо глагольных показателей, а представляют собой изолированные слова, используемые для обозначения предшествования [Валл, Канакин, 1990, с. 82].

При использовании в прошедшем времени служебных компонентов овыл'да / овыл'ден неглагольный предикат утрачивает лично-предикативное оформление (т. е. не оформляется согласовательными предикативными аффисами ряда $\partial u / \partial y$ ) (45). М. Н. Валл и И. А. Канакин указывают на несовместимость личнопредикативных показателей со служебным словом овыл'да/овыл'ден [Там же, c. 82], например: $а д$ оң =ди 'я здоров' - ад оң обил'да 'я здоров был'. 
(45)

$\begin{array}{ll}\text { Бу овыл'де } & c^{\prime} e c^{\prime}=\text { duңme. } \\ \text { он. был.PAST } & \text { pека=ADESS.N } \\ \text { 'Он был на реке.' (Сказки, 1981, c. } 87 \text { ) }\end{array}$

Таким образом, отмечена следующая закономерность: неглагольное локативное сказуемое, оформленное лично-предикативными аффиксами, используется лишь в настоящем времени; в прошедшем времени при введении вспомогательно-

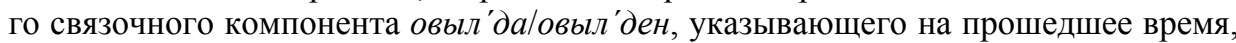
используется локативная конструкция без оформления предиката лично-предикативными согласовательными аффиксами.

Приведем примеры использования неглагольного локативного предиката в настоящем времени и прошедшем, подтверждающие вывод о том, что в прошедшем времени при введении вспомогательного компонента овыл'да/овыл'ден, лично-предикативное оформление субстантивно-послеложного сказуемого отсутствует (46), (47).

(46) Настоящее время.

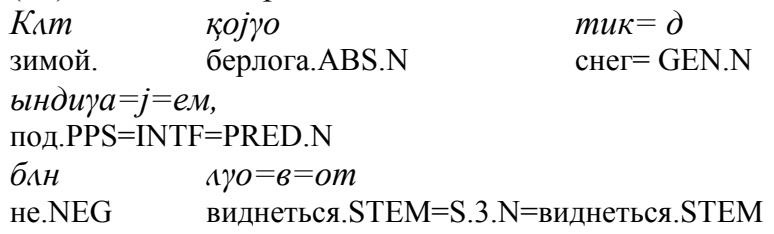

'Зимой берлога под снегом, ее не видно.' (Романенкова, 2009)

(47) Прошедшее время.

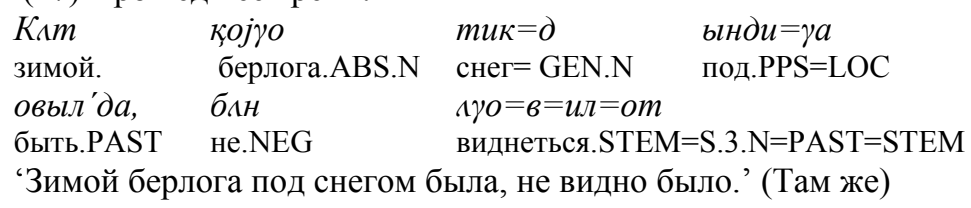

Факт взаимоисключаемости лично-предикативных суффиксов, присутствующих в настоящем времени, и вспомогательного компонента овыл'да/овыл' $\partial e=H$ в прошедшем позволяет считать последний компонент связкой, которая используется только в прошедшем времени. Невозможность одновременного использования в прошедшем времени лично-предикативных аффиксов и связки овыл' $\partial а /$ овыл' $\partial е н$ подтверждает связочный статус как лично-предикативных показателей, так и овыл'да/овыл'ден - параллельное использования двух связочных средств является избыточным и поэтому исключается.

Лично-предикативные показатели можно отнести к разновидности флективных связок по классификации, предложенной в [Curnow, 2000, p. 3-4]. Флективные связки формально совпадают с некоторыми глагольными субъектнообъектными показателями (в кетском языке выделено как минимум восемь парадигматических рядов субъектно-объектных показателей, которые закреплены за различными структурными и лексико-семантическими типами глагольных слов [Крейнович, 1968a, с. 22-23]), но отличаются от них функционально. В отличие от глагольных показателей, которые могут занимать префиксальную и инфиксальную позицию в глагольной словоформе, лично-предикативные показатели занимают иную морфо-синтаксическую позицию: при неглагольном предикате они могут заполнять только правую маргинальную (суффиксальную) позицию. При этом неглагольный предикат не переходит в разряд отыменных глагольных образований (подробности см.: [Буторин, 2015, с. 145-148]). 
Таким образом, в настоящем времени функцию связки выполняют личнопредикативные аффиксы, а в прошедшем - связка овыл'да/овыл'ден.

Будущее время неглагольного сказуемого выражается таким же образом, как и в глагольном сказуемом: посредством препозитивной частицы $a c^{\prime} / a c^{\prime \prime}$ (специализированные глагольные аффиксы, выражающие будущее время в структуре финитной глагольной словоформы, в кетском языке отсутствуют). В отличие

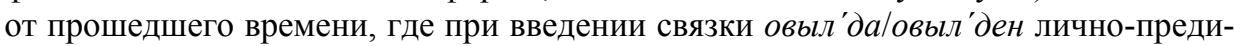
кативные показатели не используются, в будущем времени при использовании частицы будущего времени $a c^{\prime} / a c^{\prime}$ эти показатели сохраняются (48).

\section{(48)}

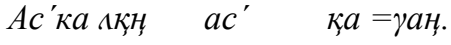

$$
\begin{aligned}
& \text { когда вы FUT дома=PRED.2.PL.AN } \\
& \text { 'Когда вы будете дома?' (Дульзон, 1972б, с. 74) }
\end{aligned}
$$

Возникает вопрос: не является ли частица $a c^{\prime} / a c^{\prime} н$ частицей-связкой? Связкичастицы отмечены в некоторых языках, например в ирландском [Curnow, 1999]. На поставленный вопрос следует ответить отрицательно, так как эта частица является стандартным средством выражения будущего времени как в глагольном, так и в неглагольном сказуемом. Приведем пример использования $a c^{\prime} / a c^{\prime} н$ при глагольном сказуемом (49).

\begin{tabular}{llll}
$(49)$ & & \\
$V$ & блjв', & дит' & \multicolumn{1}{c}{$c^{\prime}$} \\
ты.ABS & сирота.ABS & она.ADES.F & FUT \\
$\kappa=$ = $a=c=a$ & & \\
S.2=дрова.STEM=PRES=рубить.STEM & \\
'Ты сирота, ей всегда будешь дрова рубить.' [Крейнович, 1969, с. 23]
\end{tabular}

\section{4. Позиционные глаголы}

Необходимо отметить, что статические локативные ситуации местонахождения могут обозначаться как локативными конструкциями с неглагольным сказуемым, так и конструкциями с глагольным предикатом, в которых предикат выражен глаголом положения в пространстве (позиционным глаголом).

К основным позиционным предикатам могут быть отнесены стоять, сидеть, лежать, которые описывают три разных положения человека в пространстве: вертикальное - стоять, горизонтальное - лежать и «промежуточное» положение человека, которое предложено условно называть «сложенным», - сидеть. Данные предикаты в русском языке применимы не только к человеку, но и к ряду животных, а также предметов [Рахилина, 1998, с. 69-70].

Следовательно, можно выделить три основных локативных состояния 'нечто находится в вертикальном положении относительно ориентира', 'нечто находится в горизонтальном положении относительно ориентира' и 'нечто находится в «сложенном» положении относительно ориентира', которые в результате метафорического переноса применяются к животным и предметам. К этим трем состояниям и выражающим их глаголам целесообразно добавить состояние 'висеть' / ‘быть подвешенным’. В ряде языков инвентарь позиционных глаголов, вероятно, может быть расширен.

Таким образом, позиционные предикаты указывают не только на местонахождение локализуемого объекта относительно ориентира, но и на положение объекта в пространстве. 
Примечательно, что одна и та же локативная ситуация, например ситуация Ружье находится в амбаре, может передаваться как неглагольной статической локативной конструкцией с субстантивным сказуемым, в котором предикат оформлен показателем адессивного падежа (50), так и глагольной локативной конструкцией с глаголом позиции 'лежать' и локализатором, имеющим адессивное (51) или локативное падежное оформление (52).

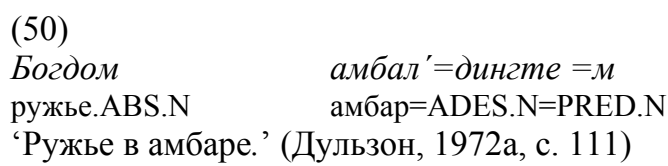

$\begin{array}{lll}\text { Богдам } & \text { амбар }=\partial^{\prime} \text { ингт } & m=a=\sigma=\text { om. } \\ \text { ружье.ABS.N } & \text { амбар=ADES.N } & \text { DET=PRES=лежать.STEM }\end{array}$

'Ружье в амбаре лежит.' (Там же)

(52)

$\begin{array}{lll}\text { Каскет } & \text { богдот'=ке } & m=c^{\prime} e: c^{\prime}=m e \\ \text { каскет.ABS.M } & \text { очаг=LOC } & \text { S.3=сидеть,STEM=сидеть.STEM } \\ \text { 'Каскет у костра сидит.' (Сказки, 1981, с. 6) }\end{array}$

Заключение

В результате анализа формальной структуры и семантики неглагольных локативных предикатов местонахождения в кетском языке можно сделать вывод, что субстантивно-послеложные и прономинально-послеложные предикаты обладают композиционной пространственной семантикой: существительное или местоимение указывает на ориентир, основа послелога называет топологическую зону окрестности ориентира (верх, низ, пространство внутри ориентира и т. д.), показатели локативного и адессивного падежей, входящие в состав послелога, выражают эссивное значение (местонахождение), предикативный показатель служит средством согласования (координации) предиката по категориям лица, числа и класса или только числа с подлежащим, являющимся локализуемым объектом. Композиционный характер семантики локативных выражений характерен и для ряда других языков, в частности уральских и тюркских [Kracht, 2002, с. 159-160; 2005; Невская, 2005, с. 139-143]. Другие разновидности неглагольного предиката, в частности субстантивные предикаты, оформленные показателями локативного и адессивного падежей, указывают на местонахождение локализуемого объекта относительно ориентира в общем виде, не конкретизируя топологические зоны.

В качестве ориентира в локативных конструкциях с неглагольным предикатом используются как предметные, так и личностные ориентиры. Предметные ориентиры представлены в конструкциях с субстантивными, субстантивно-послеложными предикатами, а также в конструкциях с предикатами, выраженными описательными оборотами с пространственными именами. Личностные ориентиры могут быть использованы в конструкциях с субстантивными, субстантивнопослеложными (при недейктически заданном ориентире), прономинальными, прономинально-послеложными предикатами, а также с предикатами, выраженными описательными оборотами с пространственными именами (при дейктически заданном ориентире). Специфика адвербиального предиката состоит в том, что он имеет особый характер локализации: неточной, а также дейктической локализацией и исключает наличие предметных и личностных ориентиров. 
При кодировании неглагольных предикатов местонахождения используются в основном две стратегии: лично-предикативная и нелично-предикативная. Лично-предикативные показатели служат средством согласования неглагольного сказуемого с подлежащим предложения (иными словами, средством координации между подлежащим и сказуемым), указывая на лицо, число и класс подлежащего. Отмечены случаи опущения лично-предикативных суффиксов. Нелично-предикативный показатель $c^{\prime} / c^{\prime}=u н$ выражает лишь синтаксическую связь координации между подлежащим и неглагольным сказуемым по категории числа, не координируя по категориям лица и класса подлежащего.

Лично-предикативное оформление отмечено лишь в настоящем времени. В прошедшем времени при прибавлении вспомогательного компонента овыл'да/обыл' $a$ (ед. ч.), овыл' $\partial e=\mu /$ обыл' $e=\mu$ (мн. ч.; $=\mu-$ показатель множественного числа) лично-предикативные суффиксы отсутствуют. Итак, флективная связка, выраженная лично-предикативными суффиксами, используется лишь в настоящем времени, в прошедшем времени функцию связки выполняют служебные компоненты овыл 'да/обыл' да и овыл'де $=$ н/обыл 'де $=$ н.

Связочная функция лично-предикативных суффиксов в настоящем времени представляется универсальной для кетского языка при оформлении не только локативного, но и других типов неглагольного сказуемого.

В заключение хочется подчеркнуть, что в качестве эквивалентов глагольных предикатов, включающих экзистенциальные глаголы типа русского находиться, которые отсутствуют в кетском языке, выступают неглагольные локативные предикаты, а также позиционные предикаты. Иными словами, ведущими моделями, выражающими пропозицию местонахождения, являются модели с использованием неглагольных предикатов и глаголов позиции (положения в пространстве), таких как стоять, сидеть, лежать, висеть. Последние подлежат отдельному исследованию.

\section{Список литературы}

Арутюнова Н. Д. Предложение и его смысл. М.: Наука, 1976. 383 с.

Буторин С. С. Общая характеристика неглагольных локативных предикатов в кетском языке // Сибирский филологический журнал. 2015. № 2. С. 142-152.

Валл М. Н., Канакин И. А. Очерк фонологии и грамматики кетского языка. Новосибирск: Наука, 1990. 100 с.

Вернер Г. К. Сложные атрибутивные конструкции в енисейских языках // Вопросы языкознания. 2000. № 3. С. 42-49.

Гак В. Г. Функционально-семантическое поле предикатов локализации // Теория функциональной грамматики. Локативность. Бытийность. Посессивность. Обусловленность. СПб., 1996. С. 6-26.

Дульзон А. П. Кетский язык. Томск: Изд-во Том. ун-та, 1968. 635 с.

Кетский сборник. Мифология. Этнография. Тексты / Под ред. Вяч. Вс. Иванова. М.: Наука, 1969.

Крейнович Е. А. Глагол кетского языка. Л., 1968а. 283 с.

Крейнович E. А. Кетский язык // Языки народов СССР. Т. V: Монгольские, тунгусо-маньчжурские и палеоазиатские языки. Л., 1968б. С. 453-473.

Крейнович E. A. Медвежий праздник у кетов // Кетский сборник. Мифология. Этнография. Тексты. М.: Наука, 1969. С. 6-112.

Мельчук И. А. Курс общей морфологии. Т. 2. Москва; Вена: Языки русской культуры: Wiener Slawistischer Almanach, 1998. 544 с.

Невская И. А. Пространственные отношения в тюркских языках Южной Сибири (на материале шорского языка). Новосибирск, 2005. 305 с. 
Плунгян В. А. Общая морфология: Введение в проблематику. М.: Эдиториал УРСC, 2000. $384 \mathrm{c}$.

Плунгян $B . A$. О специфике выражения именных пространственных характеристик в глаголе: категория глагольной ориентации // Исследования по теории грамматики. Вып. 2: Грамматикализация пространственных значений в языках мира / Под ред. В. А. Плунгяна. М., 2002. С. 57-98.

Рахилина E. B. Семантика русских «позиционных» предикатов: стоять, лежать, сидеть и висеть // Вопросы языкознания. 1998. № 6. С. 69-80.

Серээдар Н. Ч., Скрибник Е. К., Черемисина М. И. Структурно-семантическая организация предложений наличия, локализации, количества и отсутствия в тюркских языках Южной Сибири. Новосибирск, 1996. 82 с.

Curnow T. J. Towards a cross-linguistic typology of copula constructions // Proc. of the 1999 Conf. of the Australian Linguistic Society / Ed. by J. Henderson. 2000. URL: http://www.als.asn.au/proceedings/als1999/curnow.pdf (дата обращения 28.09. 2016).

Hengeveld K. Non-verbal Predication. Theory, Typology, Diachrony. Berlin; New York: Mouton de Gruyter, 1992. 321 p.

Kracht M. On the semantics of locatives // Linguistics and Philosophy. 2002. Vol. 25. P. 157-232.

Kracht $M$. The semantics of locatives in the Uralic languages // Les Langues Ouraliennes Aujourd'hui: Approche Linguistique et Cognitive / Ed. by J. FernandezVest. Bibliothèque de l'Ecole des Hautes Etudes, Sciences Historiques et Philologiques, Paris: Librarie Honoré Champion, 2005. Vol. 340. P. 145-158. URL: http://www.linguistics.ucla.edu/ people/Kracht/html/uralic-locatives.pdf (дата обращения 11.12.2016).

Vajda E. J. Ket. München: Lincom Europa, 2004. 99 p.

Werner H. Zur Typologie der Jenissej-Sprachen. Wiesbaden: Harrasowitz Verl., 1995, 214 S. (Verffentlichungen der Sociatas Uralo-Altaica; Bd 45).

Werner H. Die ketische Sprache. Wiesbaden: Harrasowitz Verl., 1997, 411 S.

\section{Список источников}

Дульзон А. П. Кетские сказки. Томск: Изд-во Том. ун-та, 1966. 164 с.

Дульзон А. П. Кетские сказки и другие тексты // Кетский сборник. Мифология. Этнография. Тексты / Под ред. Вяч. Вс. Иванова. М.: Наука, 1969. С. 167-212.

Дульзон А. П. Материалы по кетской диалектологии // Языки и топонимия Сибири. Вып. 5. Томск, 1972а. С. 104-145.

Дульзон А. П. Сказки народов Сибирского Севера. Вып 1. Томск: Изд-во Том. ун-та, 1972б. 202 с.

Романенкова, 2009 - Рукописные материалы, записанные автором статьи от информанта В. А. Романенковой в 2009 г.

Сказки, 1981 - Сказки народов Сибирского Севера. Вып. 4. Томск, 1981. 188 с.

\section{Условные обозначения и комментарии к глоссам}

1, 2, 3 - 1-е, 2-е, 3-е лицо; ABS - абсолютный падеж собственно существительного и существительного-местоимения, т. е. падеж, не имеющий морфологического оформления; ADES - адессивный (местно-личный) падеж; имеет место координация/согласование по категориям лица, числа и класса); $\mathbf{A N}$ - одушевленный класс множественного числа; показатель, совмещающий граммемы мужского и женского классов, показатели которых различаются в единственном числе; DET - детерминатив (субморф, т. е. морфема, утратившая свое значение и не поддающаяся этимологизации); F - женский класс; FUT - препозитивная 
глагольная частица будущего времени; GEN - показатель родительного падежа (генитива); INTF - интерфикс (морфонологический разграничитель), который появляется на стыке морфем, как правило, при гласном ауслауте предшествующей морфемы и гласном анлауте последующей морфемы; четкого критерия отнесения интерфикса к предшествующей или последующей морфеме при поморфемной разбивке словоформы не существует; LOC - показатель локативного (местно-временного) падежа; $\mathbf{M}$ - мужской класс; $\mathbf{N}$ - неодушевленный (вещный) класс; NEG - отрицательная частица; PL - множественное число; POSSP - притяжательное местоимение; PPS - основа послелога, которая остается после вычленения падежного (локативного) показателя; PRED - лично-предикативный или нелично-предикативный показатель; $\mathbf{S}$ - первый или единственный актант глагола-сказуемого; SG - единственное число; STEM - основа (лексическая либо основа-вербализатор, подвергнувшаяся грамматикализации и частично или полностью утратившая свое лексическое значение); таким же образом глоссируются составляющие прерывных (двухкомпонентных) основ; - знак разграничения алломорфы грамматических формантов.

\title{
S. S. Butorin
}

Institute of Philology of the Siberian Branch of the Russian Academy of Sciences Novosibirsk, Russian Federation

Novosibirsk State Technical University, Novosibirsk, Russian Federation; butorin_ss@mail.ru

\author{
Typological features \\ of expressing semantic components of location event in the Ket language: \\ a structural-semantic analysis of non-verbal predicates
}

The basic structural features and spatial semantics of the patterns expressing a static location event by means of non-verbal location predicates in the Ket language (a Yeniseian isolate) have been analyzed. The non-verbal predicate is understood in the sense formulated by Kees Hengeveld [Hengeveld, Kees. Non-verbal Predication. Theory, Typology, Diachrony. Mouton de Gruyter, Berlin - New York, 1992]. The Ket system of non-verbal predicates includes the following predicate types: substantive, substantive-postpositional, pronominal, pronominalpostpositional, and adverbial predicates as well as predicates expressed by descriptive phrases headed by certain spatial nouns. The predicate types are identified taking into account the part-ofspeech and functional character of non-verbal predicate heads.

As a result of the analysis of the predicates under study, it has been concluded that two coding strategies are used: a personal predicative strategy (a major morphological tool) and a nonpersonal predicative strategy (a minor morphological tool). The former employs suffixes of the $\partial u / \partial y$ paradigmatic suffix series coordinating the subject and the predicate in person, class (gender) in the third person singular (masculine, feminine and neuter) and the third person plural (animate/inanimate) and number (singular/plural) and the latter makes use of the suffix coordinating the subject and the predicate in number: $c^{\prime}$ in singular and $c^{\prime}=u н$ in plural.

Each type of non-verbal predicates has been described from the structural and semantic points of view. It has been shown that the structure and semantics of substantive-postpositional and pronominal-postpositional predicates have a compositional nature. The spatial semantics is expressed as follows: nouns or pronouns express a landmark, a postposition stem specifies a topological landmark area (upper, lower, front or back areas, etc.), the essive (locative and adessive) case formants mark a location. The substantive predicate has a non-compositional semantic nature: it does not specify a topological landmark area. It has been noted that adverbial predicates have either a «vague» spatial location identification or a deictic one.

Keywords: Ket language, spatial event, non-verbal predicate, structural and semantic types of non-verbal location predicates, typological features.

DOI $10.17223 / 18137083 / 59 / 12$ 


\section{References}

Arutyunova N. D. Predlozhenie i ego smysl [Sentence and its sense]. Moscow, Nauka, 1976, $383 \mathrm{p}$.

Butorin S. S. Obshchaya kharakteristika neglagol'nykh lokativnykh predikatov v ketskom yazyke [General description of non-verbal locative predicates in the Ket language]. Siberian Philological Journal. 2015, no. 2, pp. 142-152.

Curnow T. J. Towards a cross-linguistic typology of copula constructions. In: Proceedings of the 1999 Conference of the Australian Linguistic Society. J. Henderson (Ed.). URL: http:// www.als.asn.au/proceedings/als1999/curnow.pdf (accessed 28.09.2016).

Dul'zon A. P. Ketskiy yazyk [The Ket language]. Tomsk, TSU publ., 1968, 635 p.

Gak V. G. Funkcional'no-semanticheskoe pole predikatov lokalizatsii [Functional-semantic field of localization predicates]. In: Teoriya funktsional'noy grammatiki. Lokativnost'. Bytiynost'. Posessivnost'. Obuslovlennost' [The theory of functional grammar. Localization. Existentials. Possession. Conditionals]. St. Petersburg, Nauka, 1996, pp. 6-26.

Hengeveld K. Non-verbal Predication. Theory, Typology, Diachrony. Berlin, New York, Mouton de Gruyter, 1992, 321 p.

Kracht M. On the semantics of locatives. Linguistics and Philosophy. 2002, vol. 25, pp. 157-232.

Kracht M. The Semantics of Locatives in the Uralic Languages. In: Les langues ouraliennes aujourd'hui. Approche linguistique et cognitive. J. Fernandez-Vest (Ed.): Bibliothèque de l'Ecole des Hautes Etudes, Sciences Historiques et Philologiques, Librarie Honoré Champion. Paris. 2005, vol. 340. pp. 145-158. URL: http://wwwhomes.uni-bielefeld.de/mkracht $/ \mathrm{html} /$ veroeff-ling.html (accessed 11,12. 2016).

Ketskiy sbornik. Mifologiya, etnografiya, teksty [Studia Ketica. Mythology, ethnology, texts] Vyach. Vs. Ivanov (Ed.). Moscow, Nauka, 1969, 291 p.

Kreynovich E. A. Glagol ketskogo yazyka [The verb in the Ket language]. Leningrad, Nauka, 1968a, 283 p.

Kreynovich E. A. Ketskiy yazyk [The Ket language]. In: Yazyki narodov SSSR. T. V: Mongol'skie, tunguso-man'chzhurskie i paleoaziatskie yazyki [The languages of the USSR peoples. Vol. 5: Mongolian, Tungusic, and Palaeo-siberian languages]. Leningrad, Nauka, 1968b, pp. 453473.

Kreynovich E. A. Medvezhiy prazdnik u ketov [Bear feast among the Kets]. In: Ketskiy sbornik. Mifologiya. Etnografiya. Teksty [Studia Ketica. Mythology, ethnography, texts]. Moscow, Nauka, 1969, pp. 6-112.

Mel'čuk I. A. Kurs obshchey morfologii T. 2. [The course of general morphology. Vol. 2]. Moscow, Vena, Yazyki russkoy kul'tury, Wiener Slawistischer Almanach, 1998, 544 p.

Nevskaya I. A. Prostranstvennye otnosheniya v tyurkskikh yazykakh Yuzhnoy Sibiri (na materiale shorskogo yazyka) [Spatial relations in the Turkic languages of South Siberia (based on the Shor language material)]. Novosibirsk, 2005, $304 \mathrm{p}$.

Plungyan V. A. Obshchaya morfologiya: Vvedenie v problematiku [General morphology: An introduction into problem issues]. Moscow, Editorial URSS, 2000, 384 p.

Plungyan V. A. O spetsifike vyrazheniya imennykh prostranstvennykh kharakteristik v glagole: kategoriya glagol'noy orientatsii [How spatial characteristics of nouns can apply to verbs: the category of verbal orientation]. In: Issledovaniya po teorii grammatiki. Vyp. 2: Grammatikalizatsiya prostranstvennykh znacheniy $v$ yazykakh mira [Studies in grammar theory. Iss. 2: Grammaticalization of spatial meanings in the world languages]. Moscow, 2002, pp. 5798.

Rakhilina E. V. Semantika russkikh “pozitsionnykh" predikatov: stoyat', lezhat', sidet' $i$ viset' [Semantics of Russian "positional" predicates: to stand, to lie, to sit and to hang ]. Voprosy Jazykoznanija. 1998, no. 6, pp. 69-80.

Sereedar N. Ch., Skribnik E. K., Cheremisina M. I. Strukturno-semanticheskaya organizatsiya predlozheniy nalichiya, lokalizatsii, kolichestva i otsutstviya v tyurkskih yazykakh Yuzhnoy Sibiri [Structural-semantic organization of sentences of existence, localization, quantity, and nonexistence in the South Siberian Turkic languages]. Novosibirsk, 1996, 82 p.

Vajda E. J. Ket. Lincom Europa, 2004, 99 p.

Vall M. N., Kanakin I. A. Ocherk fonologii i grammatiki ketskogo yazyka [Essay on Ket phonology and grammar]. Novosibirsk, Nauka, 1990, $100 \mathrm{p}$.

Verner G. K. Slozhnye atributivnye konstruktsii v eniseyskikh yazykakh [Complex attributive constructions in the Yeniseian languages]. Voprosy Jazykoznanija. 2000, no. 3, pp. 42-49. 
Werner H. Zur Typologie der Jenissej-Sprachen. Wiesbaden, Harrasowitz Verl., 1995, 214 p. (Verffentlichungen der Sociatas Uralo-Altaica; Bd 45).

Werner H. Die ketische Sprache. Wiesbaden, Harrasowitz Verl., 1997, 411 p.

\section{List of sources}

Dul'zon A. P. Ketskie skazki [The Ket folk-tales and other texts]. Tomsk, TSU publ., 1966, $164 \mathrm{p}$.

Dul'zon A. P. Ketskie skazki i drugie teksty [The Ket folk-tales and other texts]. In: Ketskiy sbornik. Mifologiya. Etnografiya. Teksty [Studia Ketica. Mythology, ethnology, texts]. Vyach. Vs. Ivanov (Ed.). Moscow, Nauka, 1969, pp. 167-212.

Dul'zon A. P. Materialy po ketskoy dialektologii [The materials on Ket dialectology]. In: Yazyki i toponimiya Sibiri. Vyp. 5 [The languages and toponymy of Siberia. Iss. 5]. Tomsk, 1972a, pp. 104-145.

Dul'zon A. P. Skazki narodov Sibirskogo Severa. Vyp. 1 [The tales of the Siberian peoples. Iss. 1]. Tomsk, TSU publ., 1972b, 202 p.

Rukopisnye materialy, zapisannye avtorom stat'i ot informanta V. A. Romanenkovoy v $2009 \mathrm{~g}$. [Manuscript materials recorded by the author with the help of the Ket native-speaker V. A. Romanenkova during documenting session in 2009].

Skazki narodov Sibirskogo Severa. Vyp. 4 [The tales of the Siberian peoples. Iss. 4]. Tomsk, $1981,188 \mathrm{p}$ 